\title{
Ligation of water to magnesium chelates of biological importance
}

\author{
Dorota Rutkowska-Zbik • Malgorzata Witko • \\ Leszek Fiedor
}

Received: 15 December 2011 / Accepted: 3 May 2012 / Published online: 29 May 2012

(C) The Author(s) 2012. This article is published with open access at Springerlink.com

\begin{abstract}
Water binding to several $\mathrm{Mg}^{2+}$ chelates, ethylenediamine, ethylenediamine-N,N'-diacetate, porphyrin, chlorophyll a and bacteriochlorophyll a, to form five- and six-coordinate complexes is studied by means of density functional theory. The results obtained for magnesium chelates are compared with the properties of the respective aqua complexes and the influence of the permittivity of environment on the ligand binding energies is discussed. Although the most common coordination number of $\mathrm{Mg}^{2+}$ is six, in the tetrapyrrolic chelates it is reduced to five because the accommodation of the sixth water ligand results in no gain in energy. This is in line with the experimental observations made for coordination of chlorophylls in vivo. The binding between $\mathrm{Mg}^{2+}$ and water is mostly of electrostatic nature, which is supported by the finding that its energy is correlated both with the electron density of the chelator and with electrostatic potential determined at the ligand binding site.
\end{abstract}

Keywords Chlorophylls · DFT · Magnesium chelates · Porphyrins · Water

Electronic supplementary material The online version of this article (doi:10.1007/s00894-012-1459-3) contains supplementary material, which is available to authorized users.

D. Rutkowska-Zbik $(\bowtie) \cdot$ M. Witko

Jerzy Haber Institute of Catalysis and Surface Chemistry,

Polish Academy of Sciences,

ul. Niezapominajek 8,

30-239 Krakow, Poland

e-mail: nczbik@cyf-kr.edu.pl

L. Fiedor

Faculty of Biochemistry, Biophysics and Biotechnology,

Jagiellonian University,

30-387 Krakow, Poland

\section{Introduction}

Magnesium is one of the most ubiquitous metal ions in biological systems, whose role is to stabilize structures of proteins, lipid membranes, nucleotides and the nucleic acids. The stabilization is achieved by coordination of various ligands to the $\mathrm{Mg}^{2+}$ ion and the energy of the ligand$\mathrm{Mg}^{2+}$ interactions provides the stability of the complexes. Also, $\mathrm{Mg}^{2+}$ is bound as the central metal ion in chlorophylls (Chls), the major photosynthetic pigments, in which it is chelated equatorially by the tetrapyrrolic macrocycle. This type of chelation does not satisfy the coordination sphere of the central $\mathrm{Mg}^{2+}$ ion and creates a coordination center, which can host up to two axial ligands. Thus, a coordinate bond, mainly to histidine residue, is the strongest interaction that stabilizes the structures of most photosynthetic pigmentprotein complexes [1].

The coordination properties of the $\mathrm{Mg}^{2+}$ ion have been extensively studied both by experiment [1-5] and theory [6-13]. The most recent reviews of the theoretical investigation of the subject may be found in [14-17]. The ionic radius of the $\mathrm{Mg}^{2+}$ ion is relatively small $(0.86 \AA)$ and according to Pearson's classification [18], it belongs to hard ions. As such, it forms stable complexes with O-donors, while the complexes with $\mathrm{N}$-donors are somewhat less stable. In biological systems there are many types of potential ligands of $\mathrm{Mg}^{2+}$, such as carboxylic groups (aminoacid residues in polypeptides), carbonyl groups (from polypeptide backbone, aspargine and glutamine), amine groups (from protein backbone and lysine), imidazole moiety (from histidine), phosphate groups (in nucleotides, nucleic acids and lipids), and water molecules.

The crystallographic data base survey reveals that the preferred coordination number of $\mathrm{Mg}^{2+}$ is six, however the structures in which $\mathrm{Mg}^{2+}$ accommodates higher coordination 
numbers are also known [19]. The coordination number of the central $\mathrm{Mg}^{2+}$ ion in magnesium porphyrins and chlorophylls in free state (solution) can be either 5 or 6 , depending on the ligand strength [3]. However, for Chls in vivo (bound to proteins) it rarely exceeds five $[20,21]$ but a six-coordinated species was also found, e.g., in the photosynthetic antenna LH1 [2]. Interestingly, to the best of our knowledge, the species with no axial ligand or with two axially ligated water molecules were never reported [1].

The reasons for the observed mismatch in $\mathrm{Mg}^{2+}$ behavior have already been addressed, but as yet no consistent explanation of the experimental observations was proposed. Based on the experimental results, Kania and Fiedor attribute the lack of six-coordination in Chls to a drastic change of the hardness of the central $\mathrm{Mg}^{2+}$ in the chelate [22]. Ryde et al. suggest that the binding of the sixth bio-ligand would not provide any gain in energy and therefore it is thermodynamically unprivileged [9]. In a recent theoretical study, Ruiz-Lopez et al. argue that the dispersion interactions play the major role in the interactions between magnesium and axial ligands in tetrapyrrolic systems and hence are the key factors controlling the axial ligation [11]. Their results are somewhat opposed to ab-initio HF and MP2 results on various magnesium monoligated systems as well as its hexaaqua complex, which show that by passing from HF to MP2 $\mathrm{Mg}-\mathrm{H}_{2} \mathrm{O}$ interaction energy is almost unchanged [23, 24]. This discrepancy might be attributed to the fact that tetrapyrroles are more expanded, electron-rich and polarizable molecules than "simple" ligands, allowing for stronger interaction with $\mathrm{H}_{2} \mathrm{O}$. Furthermore, it is known that the structure of the magnesium complexes in proteins (with acidic and neutral ligands) depends on the permittivity of the environment, what has been reviewed in details in [14]. The influence of the nature of the environment on the structural properties of the central $\mathrm{Mg}^{2+}$ ion in tetrapyrroles has not been addressed straightforward so far. While Ryde et al. [9] report their structures as calculated in solvent through COSMO model, Ruiz-Lopez and co-workers take no environment into consideration [11] but include one explicit water molecule interacting with $\mathrm{H}_{2} \mathrm{O}$ coordinated to the central magnesium ion [12].

In view of the above, it becomes very relevant to find out how chelation of $\mathrm{Mg}^{2+}$ ion by various chelating agents, not only of tetrapyrrolic type, affects its ligand binding properties. The aim of the present study is to examine in depth the effects of $\mathrm{Mg}^{2+}$ chelation on its interactions with an additional co-ligand, in particular a water molecule, an important biological ligand. The selected chelators contain O- and $\mathrm{N}$ - donors, in accordance with the chemical preferences of $\mathrm{Mg}^{2+}$, and include: ethylenediamine (EN), ethylenediamineN,N'-diacetate (EDDA), porphyrin (Por), chlorophyll a (Chla) and bacteriochlorophyll a (BChla). They differ by the size, the symmetry and the degree of aromaticity (structures are shown in Fig. 1). EN is a simple bidentate $\mathrm{N}$-donating ligand, which might be used to model porphyrin ligand in high accuracy quantum chemical calculations, where treating the whole porphyrin ring would be computationally too demanding. EDDA is larger, with the possibility of forming four bonds with the central magnesium anion: two with deprotonated carboxylic groups and two with nitrogen lone pairs. Por, Chla and BChla are the largest four-dentate ligands, which differ by the saturation of the pyrrolic rings in the macrocycle; two pyrroles are saturated in BChla, one in Chla, and none in Por. In the present approach, Por is void of substituents, whereas Chla and BChla posses all substituents found in their native structures with the exception of phytyl chain, substituted by a hydrogen atom. Among the studied chelates only EN is neutral while the rest of them bear -2 charge, compensating the charge of magnesium ion.

\section{Methods}

Quantum chemical method based on density functional theory (DFT) with non-local Becke-Perdew functional [25-29] was applied to account for the interactions of the magnesium ions with selected ligands. The survey of literature data revealed that there are two most popular DFT functionals applied to study $\mathrm{Mg}^{2+}$ complexes: BP and B3LYP. While the latter was mainly employed to study monodentate systems, BP seems to be more often used to study tetrapyrroles, which are the important sub-group of chelates described in the manuscript. Moreover, our preliminary theoretical results showed its best performance in reproducing sixth water binding energy to $\left[\mathrm{Mg}\left(\mathrm{H}_{2} \mathrm{O}\right)_{5}\right]^{2+}$ (see Supporting materials). The calculation consisted of geometry optimizations of the studied structures and was further confirmed with vibrational analysis. The reported electronic energies were corrected for zero-point vibrational energy. The resolution-of-identity (RI) algorithm was applied in order to accelerate computation [30,31]. All-electron Gaussian type orbitals of def-TZVP quality were used to define atomic orbitals [32]. The solvation was accounted for by COSMO model [33] with default radii for the elements $(\mathrm{H}=1.30, \mathrm{C}=2.00, \mathrm{~N}=1.83, \mathrm{O}=1.72)$ and $2.00 \AA$ for magnesium. Three $\varepsilon$ values $(\varepsilon=4,20,80)$ are used in order to take into account the nature of the possible environment in which magnesium ion is located. The low permittivity $(\varepsilon=4)$ represents a non-polar environment, such as the buried cavity in protein interior, higher $\varepsilon$ value (20) relates to the cavity, which is more exposed to water, whereas the largest value represents the aqueous environment. The electronic structures of the investigated species are additionally elucidated by means of Mulliken population analysis [34]. The present results were obtained with Turbomole v. 6.3 [35]. 
Fig. 1 Structures of the studied ligands

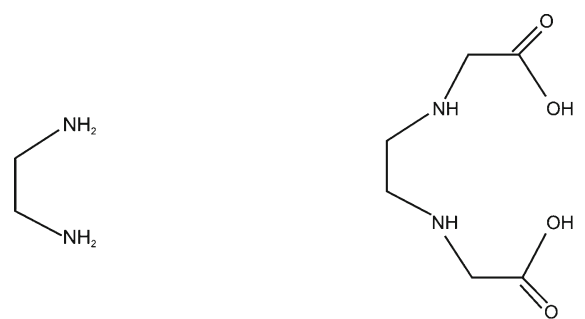

EN

EDDA

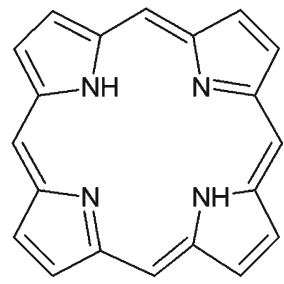

Por

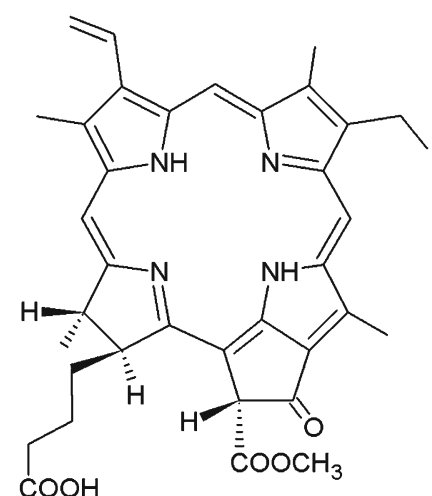

Chla

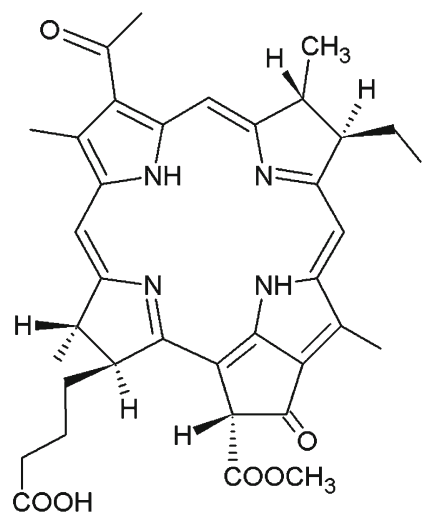

BChla

\section{Results and discussion}

Reference systems: $\left[\mathrm{Mg}\left(\mathrm{H}_{2} \mathrm{O}\right)_{5}\right]^{2+}$ and $\left[\mathrm{Mg}\left(\mathrm{H}_{2} \mathrm{O}\right)_{6}\right]^{2+}$

In order to check the appropriateness of the theoretical methodology used in the present study, first the geometry and electronic structure of the five- and six-coordinate magnesium aqua complexes have been calculated - see Table 1 . $\left[\mathrm{Mg}\left(\mathrm{H}_{2} \mathrm{O}\right)_{5}\right]^{2+}$ exhibits slightly distorted square-based pyramid geometry with all magnesium - water distances falling in the range of 2.06-2.08 $\AA$. All Mg-water distances in octahedral $\left[\mathrm{Mg}\left(\mathrm{H}_{2} \mathrm{O}\right)_{6}\right]^{2+}$ are equal to $2.13 \AA$, c.a. $0.05 \AA$ more than the $\mathrm{Mg}-\mathrm{H}_{2} \mathrm{O}$ distances found in the crystal structures of hexaaqua magnesium species [36]. The reported binding energies (see Table 1) are calculated according to the formulae:for the fifth ligand:

$\Delta \mathrm{E}=\mathrm{E}_{\text {tot }}\left(\left[\mathrm{Mg}\left(\mathrm{H}_{2} \mathrm{O}\right)_{5}\right]^{2+}\right)-\mathrm{E}_{\text {tot }}\left(\left[\mathrm{Mg}\left(\mathrm{H}_{2} \mathrm{O}\right)_{4}\right]^{2+}\right)-\mathrm{E}_{\text {tot }}\left(\mathrm{H}_{2} \mathrm{O}\right)$,

and the sixth ligand:
$\Delta \mathrm{E}=\mathrm{E}_{\text {tot }}\left(\left[\mathrm{Mg}\left(\mathrm{H}_{2} \mathrm{O}\right)_{6}\right]^{2+}\right)-\mathrm{E}_{\text {tot }}\left(\left[\mathrm{Mg}\left(\mathrm{H}_{2} \mathrm{O}\right)_{5}\right]^{2+}\right)-\mathrm{E}_{\text {tot }}\left(\mathrm{H}_{2} \mathrm{O}\right)$.

The binding energy of the fifth and sixth water in the gas phase amounts to -29.4 and $-26.7 \mathrm{kcal} \mathrm{mol}^{-1}$, respectively. These values are consistently higher by $3-4 \mathrm{kcal} \mathrm{mol}^{-1}$ than the ones determined in an electrospray experiment [4].

The inclusion of the environment polarity through the COSMO model considerably lowers ligand binding energies. In water $(\varepsilon=80)$ it is decreased by about $60 \%$.

\section{Chelates of $\mathrm{Mg}^{2+}$}

The electronic and structural parameters of the studied chelates are listed in Table 2 (five-coordinate complexes) and Table 3 (six-coordinate complexes). Geometry structures of the obtained five-coordinate complexes are shown in Fig. 2. In six-coordinate systems magnesium ion exhibits octahedral coordination. A comparison of the calculated values of the $\mathrm{Mg}-\mathrm{H}_{2} \mathrm{O}$ bond lengths with the existing crystallographic
Table 1 Calculated properties of $\left[\mathrm{Mg}\left(\mathrm{H}_{2} \mathrm{O}\right)_{5}\right]^{2+}$ and $\left[\mathrm{Mg}\left(\mathrm{H}_{2} \mathrm{O}\right)_{6}\right]^{2+}$. Energies are in $\mathrm{kcal} \mathrm{mol}^{-1}$ and bond lengths in Å. Other published results are marked in italics: ${ }^{\mathrm{a}}[6],{ }^{\mathrm{b}}[4],{ }^{\mathrm{c}}[23]$

\begin{tabular}{|c|c|c|c|c|c|}
\hline Complex & $\Delta \mathrm{E}$ (gas) & $\Delta \mathrm{E}(\varepsilon=4)$ & $\Delta \mathrm{E}(\varepsilon=20)$ & $\Delta \mathrm{E}(\varepsilon=80)$ & $\mathrm{r}\left(\mathrm{Mg}-\mathrm{H}_{2} \mathrm{O}\right)$ \\
\hline$\left[\mathrm{Mg}\left(\mathrm{H}_{2} \mathrm{O}\right)_{5}\right]^{2+}$ & $\begin{array}{l}-29.4 \\
-28.2 B 3 L Y P,-29.4 M P 2 ;^{\mathrm{a}} \\
\exp 25.5 \pm 1.3^{\mathrm{b}}\end{array}$ & -18.4 & -10.9 & -9.7 & $2.06-2.08$ \\
\hline$\left[\mathrm{Mg}\left(\mathrm{H}_{2} \mathrm{O}\right)_{6}\right]^{2+}$ & $\begin{array}{l}-26.7 \\
-25.4 B 3 L Y P,-29.1 M P 2 ;^{\mathrm{a}} \\
\exp 23.5 \pm 1.6^{\mathrm{b}}\end{array}$ & -15.6 & -12.8 & -11.8 & $\begin{array}{l}2.13 \\
2.10^{\mathrm{c}}\end{array}$ \\
\hline
\end{tabular}


Table 2 Water binding energies (in $\mathrm{kcal} \mathrm{mol}^{-1}$ ) to four-coordinate complexes of $\left[\mathrm{Mg}(\mathrm{L})_{\mathrm{n}}\right]^{\mathrm{q}}$ type determined at $\mathrm{BP} /$ def-TZVP level and $\mathrm{Mg}-\mathrm{H}_{2} \mathrm{O}$ bond lengths (in $\AA$ ). Other published results are marked in italics: ${ }^{\mathrm{a}}$ [19], ${ }^{\mathrm{b}} \mathrm{DFT}(\mathrm{BP} / \mathrm{Ri})[9]$, ${ }^{\mathrm{c}}[11],{ }^{\mathrm{d}}[37]$

\begin{tabular}{|c|c|c|c|c|c|c|c|}
\hline $\mathrm{L}$ & $\mathrm{n}$ & $q$ & $\Delta \mathrm{E}$ (gas) & $\Delta \mathrm{E}(\varepsilon=4)$ & $\Delta \mathrm{E}(\varepsilon=20)$ & $\Delta \mathrm{E}(\varepsilon=80)$ & $\mathrm{Mg}-\mathrm{H}_{2} \mathrm{O}$ \\
\hline $\mathrm{EN}$ & 2 & +2 & -21.7 & -13.7 & -10.3 & -9.6 & 2.13 \\
\hline EDDA & 1 & 0 & -17.3 & -11.6 & -8.8 & -8.2 & $\begin{array}{l}2.14 \\
\exp .2 .14^{\mathrm{a}}\end{array}$ \\
\hline BChla & 1 & 0 & -11.7 & $\begin{array}{l}-9.0 \\
-9.4^{\mathrm{b}}\end{array}$ & -7.8 & $\begin{array}{l}-7.5 \\
-8.2^{\mathrm{b}}\end{array}$ & $\begin{array}{l}2.17 \\
2.16^{\mathrm{b}}\end{array}$ \\
\hline Chla & 1 & 0 & -11.0 & $\begin{array}{l}-8.3 \\
-8.5^{\mathrm{b}}\end{array}$ & -7.1 & $\begin{array}{l}-6.9 \\
-7.1^{\mathrm{b}}\end{array}$ & $\begin{array}{l}2.19 \\
2.18^{\mathrm{b}}\end{array}$ \\
\hline Por & 1 & 0 & $\begin{array}{l}-10.2 \\
-9.5 B 3 L Y P \\
-15.8 B 3 L Y P+D \text {, } \\
-8.9 H F \\
-12.9 M P 2^{\mathrm{d}}\end{array}$ & -7.4 & -6.3 & -6.0 & $\begin{array}{l}2.20 \\
2.16^{\mathrm{c}} \\
\exp .2 .10^{\mathrm{d}}\end{array}$ \\
\hline
\end{tabular}

and/or already published theoretical parameters is not possible for all of the investigated structures due to the lack of the appropriate data. The length of the $\mathrm{Mg}-\mathrm{H}_{2} \mathrm{O}$ bond in $[\mathrm{Mg}$ (EDTA) $\left(\mathrm{H}_{2} \mathrm{O}\right)$ ] is equal to $2.06 \AA$ [19], which is shorter than the values reported in the present survey for the EDDA complexes (2.14 and $2.21 \AA$ for the five- and sixcoordinate, respectively). The computed here magnesium water distances in all tetrapyrrolic systems are in good agreement with existing experimental and theoretical values (Tables 2 and 3). In the crystal structure of the fivecoordinate $\left[\mathrm{Mg}(\mathrm{Por})\left(\mathrm{H}_{2} \mathrm{O}\right)\right]$ complex it amounts to $2.10 \AA$ [37]. In five-coordinate water adducts to Chla, the $\mathrm{Mg}-\mathrm{H}_{2} \mathrm{O}$ bond length spans from 1.87 to $2.50 \AA[38,39]$, owing to the low resolution. Theoretical calculations at the DFT-BP/Ri level by Heimdal et al. [9] give 2.18 and $2.16 \AA$ for Chla and BChla, respectively, as compared with 2.19 and $2.17 \AA$ obtained in the present study. Ben Fredj and co-authors [11] report 2.16 and $2.24 \AA$ for five- and six-coordinate porphyrin complexes calculated at the DFT-B3LYP level, respectively, which is slightly shorter than 2.20 and $2.26 \AA$ reported here. As already mentioned, no crystal structures of six-coordinate water complexes of Por, Chla and BChla are known as probably no such forms exist in nature [2].

When water molecule is coordinated by magnesium chelate to form both five- and six-coordinate adducts, the $\mathrm{Mg}$ $\mathrm{H}_{2} \mathrm{O}$ bond is longer than the one in the reference aqua complexes. The elongation is proportional to the electron density of the ligand chelating the central ion and changes in the row: $\mathrm{EN}<\mathrm{EDDA}<\mathrm{BChla}<\mathrm{Chla}<$ Por. Not surprisingly, the decrease of the $\mathrm{Mg}-\mathrm{H}_{2} \mathrm{O}$ bond energy follows the same trend. The strongest $\mathrm{Mg}-\mathrm{H}_{2} \mathrm{O}$ bond is found in the EDDA chelates, while the weakest is in Por complex. Thus, the bond strength of $\mathrm{Mg}-\mathrm{H}_{2} \mathrm{O}$ in the five- and six-coordinate systems is diminished as compared to the respective aqua complexes.

Irrespective of the polarity of the environment, water binding is always thermodynamically privileged in five-coordinate complexes. In all studied chelates $\mathrm{H}_{2} \mathrm{O}$ binding energies are negative and in the range of typical dative water - metal bonds. As in the case of the aqua structure, $\mathrm{Mg}-\mathrm{H}_{2} \mathrm{O}$ bond is weakened by $56-36 \%$ (for EN and BChla, respectively) when changing from the gas phase to the aqueous solution,

Table 3 Water binding energies (in $\mathrm{kcal} \mathrm{mol}^{-1}$ ) to five-coordinate complexes of $\left[\mathrm{Mg}(\mathrm{L})_{\mathrm{n}}\left(\mathrm{H}_{2} \mathrm{O}\right)\right]^{\mathrm{q}}$ type determined at BP/def-TZVP level and Mg$\mathrm{H}_{2} \mathrm{O}$ bond lengths (in $\AA$ ). Other published results are marked in italics: ${ }^{\mathrm{a}}[19],{ }^{\mathrm{b}}$ [11]

\begin{tabular}{|c|c|c|c|c|c|c|c|}
\hline $\mathrm{L}$ & $\mathrm{n}$ & $\mathrm{q}$ & $\Delta \mathrm{E}$ (gas) & $\Delta \mathrm{E}(\varepsilon=4)$ & $\Delta \mathrm{E}(\varepsilon=20)$ & $\Delta \mathrm{E}(\varepsilon=80)$ & $\mathrm{Mg}-\mathrm{H}_{2} \mathrm{O}$ \\
\hline EN & 2 & +2 & -17.6 & -9.1 & -5.4 & -4.6 & 2.24 \\
\hline EDDA & 1 & 0 & -8.8 & -3.9 & -1.6 & -1.0 & $\begin{array}{l}2.21 \\
\exp 2.21^{\mathrm{a}}\end{array}$ \\
\hline BChla & 1 & 0 & -6.4 & -2.3 & -0.4 & 0.0 & 2.26 \\
\hline Chla & 1 & 0 & -6.0 & -1.5 & 0.6 & 1.0 & $2.28 ; 2.29$ \\
\hline Por & 1 & 0 & $\begin{array}{l}-2.7 \\
-3.8 B 3 L Y P,-10.4 B 3 L Y P+D, \\
-1.4 H F \\
-8.3 M P 2^{\mathrm{b}}\end{array}$ & -1.1 & 0.6 & 1.0 & $\begin{array}{l}2.30 \\
2.24^{\mathrm{b}}\end{array}$ \\
\hline
\end{tabular}




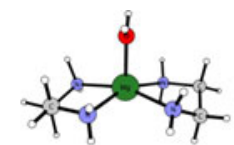

$\mathrm{Mg}(\mathrm{EN})_{2}\left(\mathrm{H}_{2} \mathrm{O}\right)$

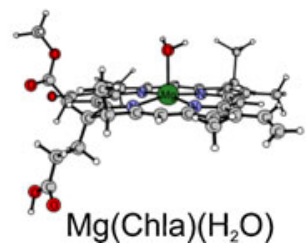

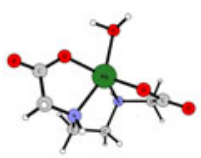

$\mathrm{Mg}(\mathrm{EDDA})\left(\mathrm{H}_{2} \mathrm{O}\right)$

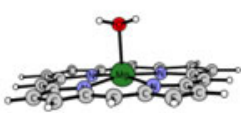

$\mathrm{Mg}(\mathrm{Por})\left(\mathrm{H}_{2} \mathrm{O}\right)$
Fig. 2 Geometry structures of the obtained five-coordinate structures

but still remains in the region of thermodynamically stable bonds.

The situation is somewhat different when considering six-coordinate structures. In gas phase, the electronic energy of water binding as the sixth ligand is always negative, indicating the ability to form the six-coordinate structures. The picture is changed when the environment is included in the theoretical model. The sixth ligand binding energy becomes either small, for EN and EDDA, or positive, in the case of tetrapyrrolic chelators. Interestingly, six-coordinate tetrapyrrolic adducts do not tend to be formed even in environments of very low polarity $(\varepsilon=4)$. This may provide an explanation for the notion that these structures are rarely found in reality - there is no net gain in energy of the whole system upon formation of six-coordinate adducts of these types.

Additionally, one should bear in mind that in aqueous media water molecules are connected by a net of hydrogen bonds. Theoretical calculations on the structure of water indicate that each $\mathrm{H}_{2} \mathrm{O}$ molecule forms $3.6 \mathrm{H}$-bonds on average [40-42]. The formation of another bond, such as with magnesium ion, would require breaking of at least one of these, with energetic penalty as high as $3-5 \mathrm{kcal} \mathrm{mol}^{-1}$. Also, in some cases, the bond formation might not be favored from the thermodynamic point of view, which was already discussed for magnesium [8]. As seen from experiment, an easy interchange of water molecules within its first and second coordination sphere is also observed for the simple hexaaqua magnesium complex [4]. At higher temperatures, the six-coordinate aqua complex undergoes relatively easy transformation to the four-coordinate species with two water molecules in the second coordination shell.

In view of the determined order of the decreasing binding ability of $\mathrm{H}_{2} \mathrm{O}$ ligand, i.e., EN $<$ EDDA $<$ BChla $<$ Chla $<$ Por, which correlates with the increasing electron density of the chelating ligand, it appears that electrostatic field of $\mathrm{Mg}$ chelates plays an important role in the binding of $\mathrm{H}_{2} \mathrm{O}$. To assess this possibility, Mulliken and Merz-Kollman population analyses have been performed and an electrostatic potential in the same position as $\mathrm{O}$ atom from water ligand has been computed (water ligand was removed whereas the geometry of the rest of the system was frozen). The analysis reveals that the charge on magnesium ion and water ligands does not vary in the series of the studied complexes. The $\mathrm{Mg}$ charge falls in the range $1.32-1.36$ (Mulliken) or $0.77-0.89$ (MK), while water molecules bear net positive charge $(0.06-$ 0.09 according to Mulliken, and $0.02-0.06$ according to $\mathrm{MK})$. The $\mathrm{Mg}$ ion interacts directly with negatively charged $\mathrm{O}$ atoms $(-0.60--0.51-$ Mulliken, $-0.86--0.91-\mathrm{MK})$. The $\mathrm{Mg}-\mathrm{H}_{2} \mathrm{O}$ binding energies correlate with the size of negative charge accumulated on $\mathrm{O}$. The electrostatic potential at the site occupied by water molecule in the six-coordinate complex is highly positive in the EN and EDDA adducts ( 0.39 and 0.48 a.u., respectively). In Chla and Bchla, the electrostatic potential is lower $\left(0.24\right.$ a.u. in each) and so are the $\mathrm{Mg}-\mathrm{H}_{2} \mathrm{O}$ binding energies. For the Por complex, however, the calculated electronic potential is neutral $(0.00$ a.u.), not fostering the effective interaction between $\mathrm{Mg}$ and water. This observation is further reflected by the lowest binding energy.

All in all, it is found that for all neutral complexes water binding energies correlate with the electrostatic potentials the correlation coefficient for the relationship is 0.99 . This indicates that in this type of compounds electrostatics would prevail in $\mathrm{Mg}-\mathrm{H}_{2} \mathrm{O}$ bonding, implying strong ionic character of the bonding. Moreover, the strength of the $\mathrm{Mg}-\mathrm{H}_{2} \mathrm{O}$ bond is largely influenced by the interaction between $\mathrm{H}_{2} \mathrm{O}$ and chelator, in particular by its electronic structure. It might arise from two factors. One may be the overall electron density of the atoms forming the immediate surrounding of $\mathrm{Mg}^{2+}$, here, e.g., the type of the basic tetrapyrrole ring: porphyrin, chlorin (Chla), bacteriochlorin (BChla). The second is due to the presence of the substituting groups, which are further apart, but due to their polarity, may largely influence the electrostatic potential at the ligand binding site.

\section{Conclusions}

1. $\mathrm{Mg}-\mathrm{H}_{2} \mathrm{O}$ bond is longer and weaker in chelates than in the respective aqua complexes. The bond elongation and the decrease of binding energy is proportional to the electron density of the chelating ligand around the central ion and change in the following order: $\mathrm{EN}<$ EDDA $<$ BChla $<$ Chla $<$ Por.

2. The formation of five-coordinate $\mathrm{Mg}-\mathrm{H}_{2} \mathrm{O}$ complexes is thermodynamically favorable, in contrast to the formation of six-coordinate complexes, in agreement with the fact that the six-coordinate complexes of Por, Chla and BChla with water are uncommon.

3. The analysis of the factors influencing $\mathrm{Mg}-\mathrm{H}_{2} \mathrm{O}$ bonding shows that the strength of $\mathrm{Mg}-\mathrm{H}_{2} \mathrm{O}$ bond correlates with 
the negative charge of oxygen atom and the electrostatic potential at the ligand binding site. These observations lead to the conclusion that the bond between magnesium and water is mostly of electrostatic nature.

4. Water binding energies are lowered (with respect to their values in the gas phase) in all the systems when the polarity of environment is taken into account in the calculations through its dielectric constant. The higher the dielectric constant the weaker the magnesium - water bond.

\begin{abstract}
Acknowledgments The work was in part supported by the Ministry of Science and Higher Education within the project No: N N204 439640 in years 2011-2014 (D.R.-Z. and M.W.) and in part by a research grant from the Foundation for Polish Science (TEAM/2010-5/ 3 to L.F.). The Faculty of Biochemistry, Biophysics and Biotechnology of the Jagiellonian University is a beneficiary of the structural funds from the European Union (grant No: POIG.02.01.00-12-064/08 - "Molecular biotechnology for health").
\end{abstract}

Open Access This article is distributed under the terms of the Creative Commons Attribution License which permits any use, distribution, and reproduction in any medium, provided the original author(s) and the source are credited.

\section{References}

1. Brindell M, Stawoska I, Orzeł Ł, Łabuz P, Stochel G, van Eldik R (2008) Application of high pressure laser flash photolysis in studies on selected hemoprotein reactions. Biochim Biophys Acta 1784 (11):1481-1492. doi:10.1016/j.bbapap.2008.08.006

2. Fiedor L, Kania A, Mysliwa-Kurdziel B, Orzel L, Stochel G (2008) Understanding chlorophylls: central magnesium ion and phytyl as structural determinants. Biochim Biophys Acta 1777 (12):1491-1500. doi:10.1016/j.bbabio.2008.09.005

3. El Alaoui El Abdallaoui H, Champmartin D, Rubini P (2001) Complexes of EDTA in aqueous solutions. Structural aspects from a 13 C NMR relaxation study. J Chem Soc, Dalton Trans (14):2153-2156. doi:10.1039/b101289o

4. Rodriguez-Cruz SE, Jockusch RA, Williams ER (1999) Hydration energies and structures of alkaline earth metal ions, $\mathrm{M} 2+(\mathrm{H} 2 \mathrm{O}) \mathrm{n}, \mathrm{n}$ ) 5-7, M ) Mg, Ca, Sr, and Ba. J Am Chem Soc 121(38):8898-8906. doi:10.1021/ja9911871

5. Drzewiecka-Matuszek A, Skalna A, Karocki A, Stochel G, Fiedor L (2005) J Biol Inorg Chem 10:453-462

6. Dudev T, Lim C (1999) Incremental binding free energies in $\mathrm{Mg} 2+$ complexes: a DFT study. J Phys Chem A 103(40):8093-8100. doi:10.1021/jp991575p

7. Dudev T, Lim C (2000) Metal binding in proteins: the effect of the dielectric medium. J Phys Chem B 104(15):3692-3694. doi:10.1021/jp9941559

8. Dudev T, Lin YI, Dudev M, Lim C (2003) First-second shell interactions in metal binding sites in proteins: a PDB survey and DFT/CDM calculations. J Am Chem Soc 125(10):3168-3180. doi:10.1021/ja0209722

9. Heimdal J, Jensen K, Devarajan A, Ryde U (2007) The role of axial ligands for the structure and function of chlorophylls. J Biol Inorg Chem 12(1):49-61. doi:10.1007/s00775-006-0164-Z

10. Bock CW, Kaufman Katz A, Glusker JP (1995) Hydration of zinc ions: a comparison with magnesium and beryllium ions. J Am Chem Soc 117(13):3754-3765
11. Ben Fredj A, Ben Lakhdar Z, Ruiz-López MF (2009) Sixcoordination in chlorophylls: the fundamental role of dispersion energy. Chem Phys Lett 472(4-6):243-247. doi:10.1016/ j.cplett.2009.03.025

12. Fredj AB, Ruiz-Lopez MF (2009) Theoretical study of chlorophyll a hydrates formation in aqueous organic solvents. J Phys Chem B 114(1):681-687. doi:10.1021/jp909380t

13. Dudev T, Cowan JA, Lim C (1999) Competitive binding in magnesium coordination chemistry: water versus ligands of biological interest. J Am Chem Soc 121(33):7665-7673. doi:10.1021/ ja984470t

14. Dudev T, Lim C (2003) Principles governing Mg, Ca, and $\mathrm{Zn}$ binding and selectivity in proteins. Chem Rev 103(3):773-787. doi:10.1021/cr020467n

15. Dudev M, Lim C (2007) Effect of carboxylate-binding mode on metal binding/selectivity and function in proteins. Acc Chem Res 40:85-93

16. Linnanto J, Korppi-Tommola J (2006) Quantum chemical simulation of excited states of chlorophylls, bacteriochlorophylls and their complexes. Phys Chem Chem Phys 8(6):663-687

17. SantaLucia J, Hicks D (2004) The thermodynamics of DNA structural motifs. Annu Rev Biophys Biomol Struct 33(1):415-440. doi:10.1146/annurev.biophys.32.110601.141800

18. Pearson RG (1963) Hard and soft acids and bases. J Am Chem Soc 85(22):3533-3539. doi:10.1021/ja00905a001

19. Stezowski JJ, Countryman R, Hoard JL (1973) Structure of the ethylenediaminetetracetatoaquomagnesate(II) ion in a crystalline sodium salt. Comparative stereochemistry of the sevencoordinate chelates of magnesium(II), manganese(II), and iron (III). Inorg Chem 12(8):1749-1754. doi:10.1021/ic50126a009

20. Oba T, Tamiaki H (2002) Which side of the $\pi$-macrocycle plane of (bacterio)chlorophylls is favored for binding of the fifth ligand? Photosynth Res 74(1):1-10. doi:10.1023/a:1020816128794

21. Balaban TS, Fromme P, Holzwarth AR, Krau $\beta$ N, Prokhorenko VI (2002) Relevance of the diastereotopic ligation of magnesium atoms of chlorophylls in Photosystem I. Biochim Biophys Acta 1556(2-3):197-207. doi:10.1016/s0005-2728(02)00363-8

22. Kania A, Fiedor L (2005) Steric control of bacteriochlorophyll ligation. J Am Chem Soc 128(2):454-458. doi:10.1021/ja055537x

23. Garmer DR, Gresh N (1994) A comprehensive energy component analysis of the interaction of hard and soft dications with biological ligands. J Am Chem Soc 116(8):3556-3567. doi:10.1021/ ja00087a049

24. Gresh N, Garmer DR (1996) Comparative binding energetics of $\mathrm{Mg} 2+, \mathrm{Ca} 2+, \mathrm{Zn} 2+$, and $\mathrm{Cd} 2+$ to biologically relevant ligands: combined $a b$ initio SCF supermolecule and molecular mechanics investigation. J Comput Chem 17(12):1481-1495. doi:10.1002/ (sici)1096-987x(199609)17:12<1481::aid-jcc7>3.0.co;2-g

25. Dirac PAM (1929) Quantum mechanics of many-electron systems. Proc R Soc Lond Ser A 123(792):714-733. doi:10.1098/ rspa.1929.0094

26. Slater JC (1951) A simplification of the hartree-fock method. Phys Rev 81(3):385-390

27. Vosko SH, Wilk L, Nusair M (1980) Accurate spin-dependent electron liquid correlation energies for local spin density calculations: a critical analysis. Can J Phys 58(8):1200-1211. doi: $10.1139 / \mathrm{p} 80-159$

28. Becke AD (1988) Density-functional exchange-energy approximation with correct asymptotic behavior. Phys Rev A 38(6):30983100

29. Perdew JP (1986) Density-functional approximation for the correlation energy of the inhomogeneous electron gas. Phys Rev B 33 (12):8822-8824

30. Eichkorn K, Treutler O, Öhm H, Häser M, Ahlrichs R (1995) Auxiliary basis sets to approximate coulomb potentials. Chem Phys Lett 240:283-289 
31. Eichkorn K, Weigend F, Treutler O, Ahlrichs R (1997) Theor Chem Acc 97:119-124

32. Schäfer A, Huber C, Ahlrichs R (1994) Fully optimized contracted gaussian basis sets of triple zeta valence quality for atoms $\mathrm{Li}$ to $\mathrm{Kr}$. J Chem Phys 100(8):5829-5835

33. Klamt A, Schuurmann G (1993) COSMO: a new approach to dielectric screening in solvents with explicit expressions for the screening energy and its gradient. J Chem Soc Perkin Trans 2 (5):799-805

34. Mulliken RS (1955) Electronic population analysis on LCAO[Single Bond]MO molecular wave functions. I. J Chem Phys 23(10):18331840. doi:10.1063/1.1740588

35. TURBOMOLE V6.3 (2011) adoUoKa, Forschungszentrum Karlsruhe GmbH -, TURBOMOLE GmbH saf, http://www.turbomole.com

36. Julian MOD, Day VW, Hoard JL (1973) Structure of hexaquomagnesium dihydrogenethylenediaminetetraacetate, $\mathrm{Mg}(\mathrm{OH} 2)$ 6H2EDTA. Stereochemistry of the uncomplexed H2EDTA2- ion. Inorg Chem 12(8):1754-1757. doi:10.1021/ic50126a010

37. Timkovich R, Tulinsky A (1969) Structure of aquomagnesium tetraphenylporphyrin. J Am Chem Soc 91(16):4430-4432. doi:10.1021/ja01044a018
38. Liu Z, Yan H, Wang K, Kuang T, Zhang J, Gui L, An X, Chang W (2004) Crystal structure of spinach major light-harvesting complex at 2.72[thinsp]A resolution. Nature 428 (6980):287-292. http:// www.nature.com/nature/journal/v428/n6980/suppinfo/ nature 02373 S $1 . h t m l$

39. Jordan P, Fromme P, Witt HT, Klukas O, Saenger W, Krausz N (2001) Three-dimensional structure of cyanobacterial photosystem I at 2.5[thinsp][angst] resolution. Nature 411(6840):909-917. http://www.nature.com/nature/journal/v411/n6840/suppinfo/ 411909a0_S1.html

40. Buch V, Sandler P, Sadlej J (1998) Simulations of H2O solid, liquid, and clusters, with an emphasis on ferroelectric ordering transition in hexagonal ice. J Phys Chem B 102(44):8641-8653. doi:10.1021/jp980866f

41. Buck U, Ettischer I, Melzer M, Buch V, Sadlej J (1998) Structure and spectra of three-dimensional $\left.\left(H_{-} \_2\right\} O\right) \_\{n\}$ Clusters, $n=8,9,10$. Phys Rev Lett 80(12):2578-2581

42. Smith JD, Cappa CD, Wilson KR, Cohen RC, Geissler PL, Saykally RJ (2005) Unified description of temperature-dependent hydrogen-bond rearrangements in liquid water. Proc Natl Acad Sci USA 102(40):14171-14174 